\title{
Global Language Politics: Eurasia versus the Rest
}

\author{
Tomasz Kamusella \\ University of St Andrews
}

\begin{abstract}
Globalization in the early 21st century can be considered as the age of inequality that splits the world into the rich North and the poor South. From the perspective of language politics, only very few discussed the division across the globe, especially, between Eurasia and the "Rest of the world." In Eurasia, indigenous languages and scripts are used in official capacity, while the same function is fulfilled almost exclusively by non-indigenous (post/colonial) European languages in the Rest of the world. In the countries where they are spoken, non-Eurasian languages have limited presence in the mass media, education, or in cyberspace. This linguistic imperialism par excellence is a long-lasting and pernicious legacy of European (western) colonialism. The aforementioned divide is strongly associated to the use of ethnolinguistic nationalism in state building across many areas of Eurasia, while this ideology is not employed for this purpose outside the region.
\end{abstract}

\section{Keywords}

Colonization; Cultural imperialism; Decolonization; Ethnolinguistic nationalism; Eurasia; Language politics; Linguistic imperialism; Scriptal imperialism

\section{Introduction}

The fall of communism in Europe (1989), followed by the dissolution of the Warsaw Pact (1991), brought the disintegration of the Soviet Union (1991), and the end of the Cold War. Because of these events, the processes of the (western in its origin) globalization of economy literally spread across the entire world. The previous trimondial socio-economic and ideological

\footnotetext{
* Tomasz Kamusella, School of History, University of St Andrews, St Katharine's Lodge, 14 The Scores, St Andrews, Fife KY16 9BA, Scotland, UK; tdk2@st-andrews.ac.uk.

I thank Catherine Gibson and Jernej Kosi for their advice and suggestions. The article benefited from the two anonymous reviewers' comments and suggestions for improvement. Obviously, it is me alone, who is responsible for any remaining infelicities.
} 
division of the globe - into the "First World" of the US-led western countries ${ }^{1}$ with capitalist (free market) economies, the "Second World" of the Soviet camp of socialist (centrally-planned) economies, and the "Third World" of postcolonial economies (often identified with the India- and Yugoslavia-led Non-Aligned Movement) - was replaced by a single world of the neoliberal consensus. This consensus entailed democracy in politics and free market (capitalism) in economy (Fukuyama 1992). However, soon it was found that that such a kind of globalization did not generate prosperity, stability and equality for all before law or in economic terms. Now, after thirty years, it is clear that authoritarianism (totalitarianism) is widely preferred to democracy. The Beijing consensus of high-tech state control looms on the horizon. The adoption of capitalism (free market-ism) for organizing economy has been much more successful. However, it split the globe into the notional rich North (for instance, including Australia, Chile or South Africa, geographically located in the south) and the poor South (for example, including Armenia, Greenland or Pakistan, geographically located in the north).

But in this economy-centered diagnosis of the current state of the world, it is very surprising to note that only little attention has been paid to language, or rather language politics and its macro-patterns. The world public opinion can be bothered only with the question whether Chinese is going to replace English as a "global language" soon (cf Gil 2019). I believe, however, that a more significant issue at stake is which languages will function as official languages in the extant states, and which languages will be used for the media of state administration, education, and public discourse. At the height of the discussion devoted to the west's continuing cultural imperialism (that is, dominance) in postcolonial (decolonized) states, the promising concept of "linguistic imperialism" was coined in 1992. But it has been predominantly brandished as a criticism of the postcommunist dogma of English being the sole global language (Phillipson 1992). Yet, the term linguistic imperialism appears to convey a much more profound insight and a wider range of meanings (cf Figueira 2013), which this article aspires to tease out. In the terms of official language use, the world can be split between Eurasia (that is, the single landmass of Asia, alongside its westernmost "promontory" of Europe) where indigenous languages tend to be overwhelmingly used in this

\footnotetext{
1 I prefer not to capitalize the politicized term "the west" and the adjective derived from it ("western"), as I do not capitalize names of political doctrines (for instance, democracy, marxism) or ideologies (for example, liberalism, nazism). To a degree, "the west" is the preferred self-appellation of post/imperial Europe and these parts of the world where European colonizers and their descendants practically exterminated indigenous populations (that is, in North America or Australia). On the one hand, this term valorizes post/imperial Europe, while on the other, conceals the dark colonial pasts, including, industrialized slavery, ethnic cleansing, and genocide.
} 
function, and the Rest of the world where almost exclusively non-indigenous European (colonial, postcolonial) languages play this role. This situation largely extends to L2 ("foreign") languages, formally acquired at school or on his/her own.

This deep cleavage, synonymous with linguistic imperialism, underpins global culture, and as such determines the dynamics of inherently unequal relations existing in all other spheres of human activities, whether it be economy, politics, or social relations. Human groups (nowadays known as "states" and "nations") bond and interact through language only. However, language-ingeneral (the English term, which takes no article or plural ending)—or the biological capacity for speech-comes in diverse varieties (actualizations of the aforementioned capacity), or languages (the English term that does take articles and the plural ending). Each such a variety, $a$ language, is a message in its own right, produced, maintained, and molded by a group of people (that is, a speech community). Every language is a product of and also reflects the values and interests of its speech community, alongside power relations within the human group. Although it is often proposed, no language is a neutral channel for conveying information. There are no universal languages in this sense. What is universal in this context is the evolutionary (biologically generated) human capacity for speech (or the article-less language-withno-plural-ending). It is worth emphasizing that the primary (evolutionary) function of this capacity is to facilitate the bonding of humans into groups, not communication which at best is a secondary function of non-biological character, hence with no immediate evolutionary significance (Dunbar 1992; Dunbar 2010: 21-34).

\section{European Model of Einzelsprache}

The two radically different concepts are, unhelpfully, conveyed with the same English word "language." In this article, I use the German specialist term Einzelsprache ( $\mathrm{pl}$ Einzelsprachen) for denoting the aforementioned varieties, that is, actualizations of the evolutionary capacity for speech in order to disentangle the ensuing terminological confusion between these two lookalike terms. In turn, this biological capacity is known as Sprache in German. Sprache is one of an array of biological (evolutionary) features that characterize humans as a species. Sprache (language, speech, and its physiology) is part and parcel of the hard-wiring ("hardware") of the human body. On the other hand, Einzelsprachen are products of human groups, namely, products of their ingenuity, choices, and labor. 


\begin{tabular}{|l|l|l|l|}
\hline Term & $\begin{array}{l}\text { Plural } \\
\text { form }\end{array}$ & Article & Meaning \\
\hline language/Sprache & None & None & $\begin{array}{l}\text { biological (evolutionary) } \\
\text { capacity for speech, a prod- } \\
\text { uct of nature (evolution) }\end{array}$ \\
\hline $\begin{array}{l}\text { language/ } \\
\text { Einzelsprache }\end{array}$ & $\begin{array}{l}\text { Yes }> \\
\text { languages }\end{array}$ & $\begin{array}{l}\text { Yes > a/the } \\
\text { language }\end{array}$ & $\begin{array}{l}\text { created by humans, an } \\
\text { actualization of Sprache }\end{array}$ \\
\hline
\end{tabular}

Fig. 1. Terminological conundrum explicated

Actually, nowadays when one states that "X is a language (Einzelsprache)," an extensive set of necessary conditions is entailed, but left unspoken. It is assumed - wrongly - that all know what a language (Einzelsprache) is. Everyone raised and educated in the rich North (west), or who is literate in the poor South does know from everyday practices and common uses of literacy what an Einzelsprache is. But this knowledge is tacit. Stereotypically, the technology of writing is equated with each Einzelsprache, though this technology is neither part of Sprache (that is, the biological capacity for speech) nor of any Einzelsprache, just like a photograph of a person is not the person or any part of it (cf Saussure 1983: 25). Writing is a technology for the rudimentary graphic recording of human speech (Sprache), which comes in the form of this or that Einzelsprache.

However, the western understanding and practice of producing and maintaining Einzelsprachen is ingrained in the antique (Graeco-Roman, European) in its origin dichotomy of the oral and the written. Nowadays this dichotomy is mapped by the conceptual opposition between "dialect" and "language" (Einzelsprache). This foundational norm proposes that varieties of Sprache in oral use only are to be known as "dialects," but those which are additionally recorded in writing should be seen as "languages." An additional norm ("by-norm") says that somehow closely related dialects have to be seen as "belonging to" a similarly related language. This by-norm tends to reflect the unequal relationship between a polity's politically and/ or culturally dominant center (usually, the capital) and its provinces. The government and the inhabitants of the capital speak and write "a (written) language," whereas uneducated provincials "mumble" in their (unwritten, oral) dialects, and so, now they need to become "civilized" by learning how to speak and write "properly" the capital's language. Obviously, in order to achieve a level playing field, it could be said that a language is none other than 
a "written dialect." But it is never done, because such equalization of different statuses entailed by the conceptual dichotomy would effectively disempower the capital's Einzelsprache. The role of this dichotomy of language and dialect is not to describe objectively a linguistic situation observed on the ground, but to establish, fortify, legitimize, and maintain the unequal relationship between speakers-cum-writers of the "civilized" Einzelsprache and speakers of "barbarian" (subaltern) dialects, which are deemed to be unsuitable for writing, or otherwise not worthy of such a distinction (cf Kamusella 2016; Van Roy 2019).

\section{From Religion to Ethnolinguistic Nationalism}

Until the late Middle Ages, Latin (alongside its specific Latin alphabet) was (almost) the sole language of power in western and central Europe. ${ }^{2}$ Latin was both the medium and message of this region's sole legitimate ideology of statehood creation, legitimation, and maintenance, or the religion of Catholicism. The Catholic Church with its seat in Rome was the ultimate arbiter of the proper interpretation and uses of this ideology, as expounded in the Vulgate, or in the approved Latin translation of the Bible. Similarly, in eastern Europe and the Middle East, the Greek language (with its Greek alphabet) of the Gospels and the Septuagint (that is, the approved Greek translation of the Old Testament) played the same role in the Orthodox Church, headed by the Ecumenical Patriarch in Constantinople (Istanbul). Unlike the Catholic Pope, this Patriarch allowed a restricted number of approved Orthodox translations of the Greek Bible into other languages across the (Eastern) Roman Empire ("Byzantium") and its sphere of influence. In this manner, the religiously-defined Einzelsprachen of Armenian, Georgian, (Church) Slavonic or Syriac - written in their specific scripts - were created. Finally, in the Islamic Caliphate, the Arabic language (alongside its Arabic script) of the Quran emerged. Meanwhile, within the confines of Judaism, the Hebrew language (together with its Hebrew letters) of the Torah (Pentateuch) continued to be cultivated.

The Judeo-Graeco-Romano-Islamic (or Middle Eastern) norm provided that a "true" Einzelsprache had to be the language and script of a "holy book," which was the ideological source of this or that monotheistic ("Abrahamic") religion. Ecclesiastical, temporal, and cesaropapist (ecclesiastical-cum-temporal) rulers wielded a given "holy tongue" as both symbol and medium of their legitimate

2 I do not capitalize the names of cardinal points, or the adjective "central," as long as they are employed for talking about subsections of a continent. Hence, "central Europe," but "North America," because the latter is the name of an entire continent. 
power. The Pope and Caliph forbade the written use of other languages than the "holy one," but as noted above, the Ecumenical Patriarch allowed for the limited development of Orthodox "holy by-languages." Similarly, the doctrinal Sunni-Shia division in Islam, provided the way for the re-emergence of Persian (now written in Arabic letters) among many Shia communities.

In western and central Europe, during the 15th and 16th centuries, the Hussites, the Reformation and the Counter-Reformation breached this broad norm of one script and one holy tongue per a single monotheist faith. The process was facilitated and accelerated by the invention of printing. Temporal (secular) power was distanced from its ecclesiastical counterpart, and the unequal relationship between these two was reversed. Previously the latter had been considered superior to the former, and now temporal rulers largely subjected ecclesiasts to the needs and interests of the state and monarchy. The Pope was sidelined, and each polity's power center (capital and/or royal court) was quick at enhancing its status with a new separate Einzelsprache, usually created through translating the Bible into it. All the new secular languages (Czech, French, German, or Portuguese) remained united with Latin because they were and still are written in the same Latin alphabet. Importantly, creators and users of these novel Einzelsprachen did not aspire to mold them into new holy tongues in their own right. This was one of the intellectual and political breakthroughs, which in the wake of the Thirty Years' War (16181648 ), resulted in the gradual separation of state and church across western and central Europe.

Orthodox polities led by Russia borrowed printing from western and central Europe, and emulated this model of the production of secular Einzelsprachen in the 18th and 19th centuries. Church Slavonic was replaced by the secular language of Russian in the late 18th and early 19th centuries. Thanks to this encouragement, Russian was followed by the construction of Bulgarian and Serbian as Orthodox Einzelsprachen in their own right during the last third of the 19th century. All the three secular languages retained Church Slavonic's script, namely, Cyrillic. The Orthodox Romanians, who were placed in the cleavage between Catholic-Protestant and Orthodox Europe, developed their Cyrillic-based semi-holy tongue of Romanian for their Orthodox Church already in the 16th century. Three centuries later, in the mid-1860s, Romanian literati completed this process of westernization ('modernization') by switching from "backward" Cyrillic to the "progressive" Latin alphabet for writing and printing in Romanian. Cases of replacing the holy tongue's script with another for writing and printing in a secular Einzelsprache were few. Typically, the role of such switches was to crush religious-cum-traditionalist 
opposition to westernization and to accelerate secularization. That was the case of the 1928 replacement of the Arabic script with the Latin alphabet for Turkish in the newly founded post-Ottoman Republic of Turkey.

It was the "holy book" that defined and codified (standardized) the holy tongue. The ideological importance of a religion enforced the norms of use (spelling, pronunciation, syntax, or word formation) of such a language. Grammars and dictionaries of a holy tongue functioned as supplementary textbooks and aide-mémoires for getting the basics right, whereas the very text of the holy book was seen as "god's ${ }^{3}$ words," which remained the ultimate reference for deciding on correctness of usages. Creators and codifiers of secular Einzelsprachen did not have any holy books of this type to fall back on. Initially, the logic of profit dictated employing such words and usages in translations of the Bible that would be readily comprehensible to the largest number of potential readers. Subsequent generations of literati who gained the skill of writing and reading from such translations acquired the tendency to avoid local ("dialectal") usages in writing by default. This "principle" and other customs of the "appropriate" manner of writing and reading an Einzelsprache were recorded and systemized in grammars of such a secular language. Its vocabulary was standardized, systematized, and broadened in bilingual dictionaries, which initially paired it with the holy tongue's lexicon, and then also with other important Einzelsprachen. The importance of an Einzelsprache was and still is decided and dictated by the economic, political, and military might of the polity, which claims and espouses such an Einzelsprache as its own.

The initial stage of standardization was reached with the production of a multivolume authoritative monolingual dictionary in which the Einzelsprache's vocabulary was defined and explicated in the very same language. Such a monolingual dictionary was typically commissioned, compiled, and provided the seal of approval by a given polity's Academy of Sciences. Often, an "academy dictionary" of this kind came in tandem with an "academy grammar" (cf Considine 2017). Both became the basis for correct usage that is spread through school textbooks, and checked upon and reinforced by all kinds of entrance examinations to universities and civil service positions. Based on these foundations, other references were compiled and thus confirmed the "modernity" (that is, western character, or the recognized compliance with the western concept and model of "a language") of an Einzelsprache. It should

3 As in the case of the names of ideologies that I do not capitalize, likewise, I prefer not to capitalize the name of the sole divinity in the indigenous monotheistic (Abrahamic) religions of the Middle East and Europe. However, not to flout the accepted orthographic conventions too much, I capitalize names of the mentioned religions. 
be noted that follow-up reference works of this type included a multivolume encyclopedia of "all knowledge," a spelling (orthographic) dictionary for masses only with rudimentary elementary education, or a pronunciation dictionary for theater actors and radio speakers. The rise of the ubiquitous press and cheap books gradually bridged the chasm between the hardly literate poor and the rich literati. Then scholarly-cum-political projects of etymological and historical dictionaries of the Einzelsprache in question were considered. The former joined the Einzelsprache's speech community with "civilizationally, culturally and racially respectable" speech communities of other, especially "important," languages. On the other hand, framers of historical dictionaries usually laid claim to a chunk of space and time (that is, written and printed material from such an area and period), which they saw as suitable for the perceived "greatness" of their Einzelsprache and state (kingdom, empire, republic).

The isomorphic (overlapping) and homogenizing in its character normative model of one faith, one holy tongue and its equally "holy" script was gradually fitted to the needs of secular politics. In the epoch of "enlightened absolutism" (from the mid-18th to mid-19th centuries), a holy tongue and/or multitude of secular languages used for administration across a single polity's regions were reduced and replaced ideally with only one indigenous Einzelsprache, written in a single script. This normative compulsion, for instance, underpinned the 1784 decision to replace Latin (and some other languages) with German across the Habsburg lands (known as the Austrian Empire since 1804) (Judson 2016: 80).

Meanwhile, the French Revolution brought nationalism to European politics as the leading ideology of statehood creation, legitimation, and maintenance. This ideology proposes that the nation ${ }^{4}$ is the highest "taxonomic" kind of human group possible and that only nations have the right to their own statehood. Nationalists believe that humanity is "naturally" divided into nations; hence, the initial task was to replace the non-national political map of Europe with nation-states, or states for one nation only. In France, this goal was achieved by declaring that all the country's inhabitants are equal citizens. Furthermore, by the virtue of this declaration, the French citizens are construed together as the French nation. Hence, in this arrangement, the state equates the nation (cf Weber 1976).

4 Proponents of the ideology of nationalism often overlook the fact that this ideology, alongside the very term "nation," are artifacts of human creativity and imagination. Thus, for instance, for over two millennia, the Latin in its origin word "nation" has been deployed for denoting different things during different periods of time in different regions of Europe and the Middle East (cf Kemiläinen 1964). 
Because of a variety of reasons, such a polity-centered pattern of nation- and state-building (or civic nationalism) was rejected in central Europe. During the course of the wars against Napoleonic France, a new understanding of the nation was proposed at the turn of the 1810s, namely that all speakers of a given language should constitute a nation. Speech community was equated with the nation in this manner, which is the basic defining feature of ethnic (ethnolinguistic) nationalism. Whereas a stateless civic nation is considered an impossibility, the majority of ethnic nations usually start as stateless national movements (Hroch 1985). As a result, the period between the 1848 revolutions and the end of the Great War was marked in central Europe by the emergence of ethnolinguistic nation-states that eventually replaced the region's non-national empires.

\section{Colonization}

As mentioned above, the early modern period in western and central Europe was marked by the creation of secular Einzelsprachen. The rise of science, unshackled from the ideological limitations imposed by religious taboos (dogmas), contributed to relative political stability and economic prosperity, which followed after the end of religious wars. As a result, the steep growth in population and economic resources was utilized for the sake of colonization, which meant overseas territorial expansion in the case of western Europe's polities (also known, as "great powers"). The traditional thinking on European colonial empires defined colonization simplistically as the process of establishing settlements (colonies; from Lat. colōnia 'settlement'). But, in the definition, no attention is paid to the ethnic dimension of this process. Europeans (for instance, Dutchmen, Englishmen, Frenchmen, Scots, Spaniards, or Portuguese) sailed to a non-European territory, and claimed it for their home country. In other words, they stole ("annexed, seized") by trick or force a tract of land of the local non-European indigenous inhabitants, with the intention of founding a European settlement (usually, a military or militarized outpost) in the midst of a non-European population, obviously without getting their consent. If non-Europeans disagreed with such an imposition, they were typically massacred and enslaved with the use of "superior" weaponry or treachery. Furthermore, European diseases inadvertently brought along by European conquerors and land thieves often decimated non-European populations, especially in the Americas and Australasia (Crosby 1986).

In Europe, agriculture remained the dominant sector of economy until the mid-19th century. Land was the main measure and generator of wealth. 
Unsurprisingly, colonizers went overseas mainly in search of arable land. How did they justify their theft of land from indigenous non-European owners and ethnic groups? At that time, despite gradual secularization, the Bible remained the foundation of European law and morality. Moreover, the Bible is an intellectual product of Middle Eastern agriculturalists and their societies. According to their perspective, it is unjustifiable to allow land "lie fallow." Such a land, by definition, is considered as "ownerless" from the biblical perspective. Hence, whenever an agriculturalist stumbles across "fallow land," he can legally "take it into possession." It does not matter that huntergatherers or pastoralists may use and take care of this land, together with its fauna and flora, to ensure livelihood for their families and communities. According to the biblical-cum-European legal perspective as long as land is not cultivated in accordance with a form of agriculture recognized in Europe, people living in such a land are seen as unable to own it. As a result, colonizers could "legally" steal lands of this type, and chase away, enslave, or exterminate its original non-European and non-agriculturalist owners (Churchill 1993; Harring 1998).

Colonization is none other than naked land grabbing, violent and unjustified looting from the perspective of the original non-European owners. However, at times, in the "New World," conquistadors came across ethnic groups who practiced agriculture and lived in formally organized states. Posed with this dilemma, the colonizers justified their looting by stating that non-European populations knew nothing about the "good news" of Christ. This means that their ownership of land was invalid till they became Christians. The colonizers also emphasized that the non-European "heathens" could hear about Christ due to the former's "good will." This message was deemed more indispensable and precious than anything else in this world. Hence, it appeared justifiable that the colonizers should be rewarded with the land of the converted heathens (or "New Christians") (cf Foreman 1932) because of this unique service (of cultural destruction).

The colonial land grabs and the subjugation of non-European ethnic groups was accompanied by the imposition of the European cultural and socioeconomic package. At first, the process entailed the destruction of indigenous culture, making indigenous ethnic groups into "people without history" (Wolf 1982). This package's socio-economic element was gradually translated into agriculture and capitalism, while its cultural constituent stemmed from the Bible as the source of legislation and morality. But, in terms of language policy, it was a case of the wholesale transplant of the holy tongue of Latin from Europe to a colony, alongside a given Einzelsprache of colonizers, typically 
written in the Latin alphabet. Latin was employed for spreading Christianity and justifying the forcing of this religion on colonial populations. Further, the European Einzelsprache became the colonial language of administration and of the system of socio-economic oppression imposed on non-European populations.

Until non-European communities acquired a working knowledge of European Einzelsprachen, the Bible and accompanying religious material were translated into "indigenous languages." De facto, it was missionaries-colonizers who imposed the concept of Einzelsprache and its preferred uses on the nonEuropean linguistic practices, without giving any respect to the actual needs and aspirations of non-European ethnic groups. According to missionariescolonizers' perspective, non-Europeans were "children" and could not know any better, so what they "really" needed was Christ and the Gospel. These self-appointed European colonial specialists of socio-cultural engineering did not give any importance to indigenous elite speech varieties, denigrating them as "heathenish." Instead, they usually chose the speech variety of a given mission and its vicinity, that is, where the local population and their customs had already been thoroughly subjugated and neutered. On this tabula rasa, missionaries-colonizers built a missionary Einzelsprache. Its phonemes and basic vocabulary were non-European, but its form and message (conveyed through this missionary language) were fully European and Christian (Stoll 1982).

\section{From Decolonization to Linguistic Imperialism}

In the traditional approach to this issue, it is proposed that decolonization commenced with European colonies in the Americas that successfully declared and fought for independence against European metropolises (Thurner 2019). After World War II, the maritime colonial empires of western European powers became economically and morally unviable. Most of the colonies in Africa, Asia, and Oceania were granted independence in the 1960s, which thus became known as the high age of decolonization (Thomas, Moore and Butler 2010). At present, decolonization is generally associated only with this postwar wave of colonies that became independent nation-states in the wake of the break-ups of the European maritime empires.

What is then "decolonization"? Simply speaking, this should be a process in the course of which the salient effects of colonization are swiftly and permanently reversed. But, in the political sense, it ought to mean the reinstatement of precolonial or similar indigenous forms of statehood or group organization. Not such a thing was ever attempted outside Eurasia. In most cases, colonies 
in the Americas, Africa, and Oceania were simply transformed into nationstates with the same borders and populations as those of the former colonies. In Eurasia, independent India in part was constituted on the tradition of the Mughal Empire, which had been gradually subdued between the mid18th and mid-19th centuries by British colonizers. And even more explicitly, the decolonized countries of southeast Asia (Burma, Cambodia, Laos, and Vietnam) claimed historical and political continuity with their respective precolonial monarchies. Yet, even these Eurasian postcolonial polities chose to define themselves as nation-states, in accordance with the (western) European model of (modern) statehood. In the contemporary world, this is the sole legitimate model of statehood that is now universally accepted, especially after the breakup of the Soviet Union in 1991. The Soviet Union was the world's only extensive polity, which did not define itself as a nation-state after 1945. It was seen to be a communist state, or a polity fully defined and legitimized by the non-national ideology of communism. ${ }^{5}$

From the socio-economic perspective, decolonization should be about the returning of stolen land to indigenous inhabitants or their descendants. This program was implemented in these postcolonial nation-states where indigenous ethnic groups survived the colonial period and constitute the majority till date, or at least a sizeable plurality of the population; namely, in Eurasia and Africa, and on some island states of Oceania in the south Pacific. On the other hand, indigenous ethnic groups of the Americas, Australia, and New Zealand were either exterminated or thoroughly marginalized. Hence, land remains in hands of colonizers and their descendants in the postcolonial countries established across these areas. In addition, millions of slaves were captured in Africa between the 16th and 19th centuries and they were transported to the Americas. And during the last two centuries, millions of immigrants - first, from Europe, and then from across Eurasia - have arrived to the colonies or postcolonial states. Such polities in the unrepentant colonial-like vocabulary are known as "settler countries" (cf Cavanagh and Veracini 2017), while critics refer to the continents with countries of this type as "Neo-Europes" (Crosby 1986: 11). The neologism indicates that original indigenous ethnic groups were replaced in ethnic, cultural, economic, and biological (genetic) sense by Europeans, or more broadly, Eurasians.

From the cultural sense perspective, decolonization ought to be about the reintroduction of precolonial or similar practices in the sphere of group beliefs

5 Obviously, the "known unknown" of the European Union may complicate this picture in the future, should the majority of its member states agree that this de jure "international organization" is a polity. In such a case, unless an All-European nation is proclaimed, the EU may become a new-style nonnational state. 
("religion, morality"), social cohesion ("art, culture, folklore"), and language politics ("Einzelsprache"). However, this kind of reversal was (to a degree) possible only in these postcolonial countries where indigenous ethnic groups constitute the majority of the population and managed to preserve such precolonial cultural practices. Hence, the reversal of this kind turned out to be unworkable in the Neo-Europes of the Americas and Australia. So totally, a cultural reversal of colonization took place only in Eurasia's postcolonial nation-states, especially in southeast Asia. ${ }^{6}$ In Africa, indigenous ethnic groups constitute the majority of the population, but in most cases the local religions were replaced either with Christianity, or in some cases with Islam (cf Achebe 1958). By maintaining stable and regular worldwide sailing and train routes, European colonialism - rather inadvertently - facilitated the spread of Islam across Eurasia and Africa.

Finally, the replacement of colonial European languages in the postcolonial nation-states located in the Neo-Europes proved an impossibility. Until now, American or Australian languages are marginalized, neglected, and disparagingly labeled as "native." It is indigenous Americans or Australians who are expected and pressurized by school and state administration to acquire a given colonial European language, not the other way around.? In Africa, where there are few European settlers, upgrading a missionary indigenous Einzelsprache to the status of a national or official language was a viable option. However, colonial European Einzelsprachen were retained as official or state languages in the interest of maintaining a proverbial level playing field for typically highly multiethnic and polyglot populations observed in the postcolonial nation-states. The trend became "normalized" to a high degree, so that it was followed even in such ethnolinguistically homogenous polities as Burundi, Madagascar, or Rwanda. This very sociolinguistic reality on the ground defines what I see as "linguistic imperialism." European colonial empires and colonial administrations left half a century or longer. But the legacy of colonial European languages remains largely unchallenged even in

6 Of course, it was not a reversal to how things had been in the precolonial times. The meaning intended here is mainly limited to returning to the use of indigenous languages in official contexts, from which colonial languages were phased out.

7 Graduate students in the United States have a language requirement as part of their PhD programs. Sadly, almost no American history PhD students choose to take an elective in "Native American languages," even though this would be an obvious enrichment for many research topics. (I thank Catherine Gibson for this remark.) 
these postcolonial countries where it would be relatively easy and politically unproblematic to replace them with indigenous Einzelsprachen. ${ }^{8}$

Indigenous languages, reshaped (that is, "modernized, westernized") in emulation of colonial European languages, were (re-)introduced as national and official ones only in some Eurasian postcolonial nation-states. It appears that this process turned out to be swifter where an indigenous script survived (or was freshly developed) for writing and printing in a non-European Einzelsprache, and such examples are Bangla (Bengali) in Bangladesh, Burmese in Burma, Hindi in India, Khmer in Cambodia, or Lao in Laos. But, in southeast Asia the national languages of Filipino in the Philippines, Indonesian in Indonesia, Malaysian in Malaysia, and Vietnamese in Vietnam are written and printed in the European alphabet of Latin letters. In the last case of Vietnam, it appears to be an attempt to stem the continuous (and still) strong influence of Chinese culture, script, and language in this country. Moreover, in Indonesia and Malaysia, and partly also in the Philippines, the preference for the Latin alphabet may be due to the 19th-century western belief that the Arabic script was not suitable for "modern" languages. This pernicious stereotype persisted until the mid-20th century (Burrows 2016: 32).

The more prevalent or weaker presence and the de facto or coofficial use of former colonial European languages in south and southeast Asian nationstates appears to be related to the dominant form of nationalism employed for statehood construction, legitimation, and maintenance. For instance, India is a highly polyglot, multiethnic, and polyconfessional nation-state, with a population twice the size of Europe's. Hence, only civic nationalism offering equal Indian citizenship to everyone ensures the same common denominator to all that binds the highly diverse population into the Indian nation and makes the Indian nation-state possible. As a result, although the Indian Constitution designates Hindi as the country's national language, de facto it is the European Einzelsprache of English that fulfills this role ${ }^{10}$

8 However, there are precious few postcolonial countries that are as ethnolinguistically homogenous as Burundi, Madagascar or Rwanda. In the vast majority of colonies, European powers followed the logic of divide et impera ("divide and rule"). Different precolonial polities and ethnic groups were put together (often against their will) in a colony or split into fragments among different colonies, so that not a single indigenous group or pre-colonial elite could challenge European colonizers. As a result, the latter became the ultimate arbiters and controllers among various conflicted indigenous ethnic groups and former elites in a colony. This technology of imperial rule prevented and still prevents the emergence of a consensual indigenous official language in the majority of postcolonial nation-states, which ethnically and territorially are continuations of former colonies.

9 According to the Indian Constitution, Hindi is the sole official language of the entire country (Article 343 1949).

10 Apart from Hindi and English, 21 other India's languages are employed in official capacity at the regional (provincial) level of India's states (Constitutional 2020). 
(Benedikter 2009: 32-35). The aforementioned nation-states of southeast Asia are located at the other end of the continuum of nationalism. All of them (including Thailand, which was never colonized, with Thai as its official and national language) opted for ethnolinguistic nationalism, including even such a multilingual polity as Burma. ${ }^{11}$

Pakistan is an interesting in-between case. Its main ideological foundation is based on ethnoreligious nationalism, which is clearly announced by the formal designation of this country as an "Islamic republic." Urdu is Pakistan's national language, while English fulfills the role of the preferred official language, just like in neighboring India (Constitution 2012: Art. 251). However, less than eight percent of Pakistan's population speaks Urdu as their first language ("mother tongue") (Government 2014), while three quarters of all Urdu-speakers live in India (Breton 1999: 183; Gunnemark 1992: 90). So Urdu is a "foreign" (L2) language in Pakistan from this perspective, yet it is indigenous to the Indian subcontinent (Rahman 2011). The situation in Indonesia is also similar, where less than a fifth of the inhabitants speak the country's national and official language of Indonesian as their first language (Penduduk 2012: 421, 427). However, Indonesian is indigenous to the country, and no European language plays any official role in Indonesia, unlike in Pakistan.

\section{Red (but Not So Thin) Line of the Global Cleavage}

Nowadays, the entire world's habitable territory (that is, less Antarctica) is divided among the extant nation-states. However, polities organized in line with the logic and assumptions of ethnolinguistic nationalism are limited to Eurasia, while civic nationalism is the prevalent ideology of statehood creation, legitimation and maintenance in the Rest of the world. In terms of language politics, indigenous Einzelsprachen are employed as official (state, national, administrative, or working) languages in Eurasia's polities, though in some countries post/colonial ${ }^{12}$ European languages may be used for "back-up" or

11 Obviously, this generalization does not cover the special cases of such mini-polities as Brunei or Singapore.

12 I use the somewhat neologism-like form of the term "postcolonial," namely, "post/colonial," in order to signal the, at present, confusing and quite confused ideological status of European Einzelsprachen in use outside Europe. When European colonial empires still thrived, there was no doubt that these were straightforwardly "colonial languages." Now when the empires already disappeared, most prefer to refer to these European Einzelsprachen as "postcolonial languages" by direct analogy to the label "postcolonial state," typically applied to former colonies-turned-independent nation-states. However, the very fact of sticking to former colonial European languages in postcolonial states indicates that political independence does not equate cultural-cum-social independence. This ambivalence is characteristic of linguistic imperialism, that is, the continuing employment of former colonial European languages in postcolonial nation-states. 
"acknowledged non-national" roles. On the other hand, almost in all cases outside Eurasia non-indigenous Einzelsprachen function as official languages in the extant nation-states. Among the vast majority, these languages are just a handful of post/colonial European Einzelsprachen. Symptomatically, not a single "Rest" (non-Eurasian) Einzelsprache is employed in the function of an official (state) language in a Eurasian polity.

\begin{tabular}{|l|l|l|l|}
\hline Area & $\begin{array}{l}\text { State (official) } \\
\text { languages }\end{array}$ & $\begin{array}{l}\text { Type of } \\
\text { nationalism }\end{array}$ & Population \\
\hline Eurasia & indigenous & $\begin{array}{l}\text { ethnic } \\
\text { (esp. ethnolinguistic) }\end{array}$ & 5.3 billion (68\%) \\
\hline $\begin{array}{l}\text { Rest } \\
\text { (of the world) }\end{array}$ & $\begin{array}{l}\text { non-indigenous } \\
\text { (European) }\end{array}$ & civic & 2.5 billion (32\%) \\
\hline
\end{tabular}

Fig. 2. Main features of the cleavage between Eurasia and the Rest of the world in official (state) language use

It is interesting to observe and analyze the location and dynamics of this rarely noticed or discussed line that separates Eurasia's countries where indigenous Einzelsprachen are employed as official languages from those across the Rest of the world in which non-indigenous (mostly European) Einzelsprachen fulfill this role. In the southeastern "maritime corner" of Eurasia, Papua New Guinea constitutes a significant cornerstone of this cleavage. The country shares borders with Indonesia where its indigenous Einzelsprache of Indonesian is used officially, and with Australia where English functions as the country's de facto national and official language. Papua New Guinea's official languages are English, Tok Pisin, and Hiri Motu. English is the country's former colonial language, while the two others are creoles, or "mixed" Einzelsprachen, that in their makeup draw both on English and indigenous Austronesian languages (Constitution 1975: Art. 2.11). The situation in Papua New Guinea is symbolic of official language use across today's Oceania. It is characterized by a certain use of indigenous languages, de facto or de jure deemed as national, while the dominant role is invariably bestowed on European Einzelsprachen. New Zealand, placed at the other (southernmost) end of Oceania and bordering Australia follows a similar pattern. English is the dominant language, while co-official status has been guaranteed to the indigenous Austronesian Einzelsprache of Maori since 1987 (Māori 1987: Art. $3)$. Yet, only a tiny group of 1 to 3 percent of the population speak and write this language regularly with a degree of fluency (Ngā puna 2015), while in 
Papua New Guinea practically all speak an indigenous language apart from the nation's state official languages.

Further, when the Federated States of Micronesia, Nauru, the Solomon Islands and Tuvalu are considered, English is the de facto official language, although indigenous languages exist in these polities. The same situation prevails in the US territories of Guam and American Samoa; and in New Zealand's dependencies of the Cook Islands, Niue and Tokelau. Similarly, in New Caledonia, French Polynesia, or Wallis and Futuna, which are overseas territories of France, indigenous languages are spoken, but French only is official. Hence, the situation is like in the Rest of the world.

Elsewhere across Oceania, the Eurasian model of language politics is observed. In Kiribati, the Einzelsprache of Kiribati is the country's national and official language, while in the Marshall Islands - Marshallese, in the Northern Mariana Islands - Carolinian and Chamorro, in Palau - Palauan, in Samoa Samoan, or in Tonga - Tongan. Yet, in all these island nation-states, though English is designated as an official language, it dominates de facto in public use (Constitution 1979: Art 13.1; Constitution 1994: 22.3; Constitution 1995: Art 127; Constitution 1997: Art. 54; Marshall 1995: Art. 16.5). Vanuatu constitutes a special case, in which both English and French function as the country's official and dominant languages in public life and education apart from the national language of Bislama (Vanuatu's Constitution 2013: Art. 3). Colonialism rubbed off on today's Fiji in another way. Apart from the national language of Fijian and official English, the status of a third official language was granted to the Indian (Eurasian) Einzelsprache of Hindi (Constitution 2013: Art. 3.3). Hindi is spoken by descendants of indentured laborers brought from British India to Fiji, when this island was a British colony. In the aforementioned cases, the pattern of official language use is similar to that in some south Asian countries, where an indigenous Einzelsprache is recognized as national and official language, although a European language is predominantly employed for administration and education.

Looking westward, the analyzed line of cleavage between states with indigenous or non-indigenous Einzelsprachen in official use cuts across the Middle East and north Africa. This line is not so visible in this area in the first glance. Obviously, the broad belt of territory from Mesopotamia (or today's Iraq) and the Arabian Peninsula in the east to Morocco, Western Sahara and Mauritania in the west is dominated by the Islamic countries with Arabic as their national and official language. But is Arabic - namely, the standard form of this language - indigenous to this vast area? In the seventh century, this Einzelsprache was created (codified) as the holy tongue of the Quran in 
the Arabian Peninsula. So, Arabic is indigenous only to this Peninsula based on this perspective. For other aforementioned areas, it was brought in by the invading armies of the rapidly expanding Islamic Caliphate during the seventh and early eighth centuries. In this manner, Maghreb and Mesopotamia were overhauled into "Neo-Arabias," to the exclusion from written use and the subsequent suppression of Aramaic (Syriac) in Mesopotamia, Coptic in Egypt and Berber across Maghreb. In the same manner, the Arabo-Muslim conquistadors did away with the holy tongues-cum-lingua francas of Persian, Greek, and Latin (cf. Slugget and Currie 2014: 14-19).

The adoption of Arabic in this extensive swath of land conquered by the Arabo-Muslim conquistadors was facilitated by the fact that Aramaic, Berber and Coptic, as Semitic (Afro-Asiatic) languages, were closely interrelated in structure, vocabulary, and pronunciation - with the Semitic Einzelsprache of Arabic. That is, Arabic was not so radically different like Spanish or English vis-à-vis America's indigenous languages, be it Nahuatl in Mexico or Massachusett in Massachusetts. The non-indigenous character of Arabic in Maghreb, Egypt, or Mesopotamia is observed from the language's very name that means "the Einzelsprache of the Arabian Peninsula." It is not an Egyptian, Maghrebian, or Mesopotomian language. But is standard Arabic indigenous to Arabic-speakers (that is, Bahrainis, Emiratis, Kuwaitis, Omanis, Qataris, Saudi Arabs, or Yemenis) in today's Arabian Peninsula? Should the indigeneity of an Einzelsprache be defined in the terms of it being the first language (L1) of a speech community, then standard Arabic is not indigenous to the peninsula, either. It is so, because no stable and self-reproducing speech community speaks standard Arabic as their first ("native") language. Arabic-speakers from Maghreb to Arabia and Mesopotamia speak in local Arabic dialects which are their first languages. These "dialects" are as different from Arabic as French or Italian to Latin. The standard Arabic of the Quran is removed 14 centuries from today's speech (dialects) in the Arabic-speaking countries, and as such one acquires it only in school for the purpose of writing and some limited formal oral uses. The situation is similar to medieval and early modern Europe, where Latin was the main Einzelsprache of administration and education, though its speech community had disappeared in the second half of the first millennium CE (Kamusella 2017).

Another interesting and in some ways similar is the case of the language Ivrit (Modern Hebrew), that is, the national and official language of Israel. Ivrit is purported to be a direct continuation of ancient (biblical) Hebrew. However, this Hebrew in question disappeared as a language of everyday life in the second century CE, typically replaced by the then high status language 
of Aramaic. Between that time and the early 20th century, or for almost two millennia, there was no L1 speech community of Hebrew. Yet, ancient Hebrew continued to function like "postvernacular" Latin or Arabic, used as a specialized Einzelsprache of religion, scholarship, and written communication, and continually passed from older males to boys in religious schools (yeshivas). During the last third of the 19th century in central Europe, this antiquated Hebrew was "modernized" and made into a western-style Einzelsprache on the model of Yiddish, Spanyol, German, Polish or Russian. In many ways, Ivrit can be seen as a grammatically Slavic, or Slavic-Germanic language with a Semitic lexicon (Wexler 1990). Hence, in essence, it is a European language transplanted to the Middle East in the course of the creation of Israel during the first half of the 20th century. But when considering the non-vernacular standard Arabic, Ivrit is now a vernacular Einzelsprache, with its recently created (or indigenized) speech community.

Paradoxically, the sole vernacular Arabic Einzelsprache is Maltese, or the national and official language of the Mediterranean island nation-state of Malta (Kaye 1997). It is a Maghrebian (Libyan-Tunisian) dialect of Arabic (Semitic) used both in speech and writing. Hence, the Maltese constitute the sole "dialectal Arabic" speech community whose language of everyday communication functions as a recognized Einzelsprache. Due to the vagaries of history and because the Maltese profess Catholicism, the Einzelsprache of Maltese is imbued with a lot of English and Italian vocabulary. Just like India, Malta is a former British colony, so English is employed in this country as its co-official language. Such colonial legacies in language policy can be also observed across all the Arabic-speaking countries. Due to the disjunction between the vernaculars and the standard Einzelsprache of Arabic, the post/ colonial European Einzelsprachen of English, French, Italian or Spanish continue to function in these countries as a preferred language of written communication and reading material depending on the region.

\section{Special Cases across the "Rest:" Rooting for Indigenous Languages}

South of the Arabophone Islamic belt of north Africa and the Middle East, or in sub-Saharan Africa, the post/colonial European Einzelsprache of English, French, Spanish, and Portuguese (with some walk-on roles also reserved for Arabic and German) function as sole or leading official languages. In some cases indigenous African Einzelsprachen are accorded the role of national languages, and they are employed as media of education sometimes. Yet, they are never used at the level of university. Invariably, it is a post/colonial (nonindigenous) European Einzelsprache that fulfills this role. 
Some suggest that South Africa's co-official language of Afrikaans is an indigenous African language. It is a form of Dutch preserved and developed in line with the local conditions and needs, by the descendants of the original 17th- and 18th-century Dutch colonizers in South Africa. During this process, Afrikaans became imbued with a lot of Khoisan, Bantu, and Malay (Indonesian) vocabulary, but to a large extent remains mutually intelligible with Dutch. Hence, Afrikaans can be considered as a European Einzelsprache, though not colonial in the traditional sense. Yet, the discriminatory policy of apartheid ("separateness") pursued in South Africa during the second half of the 20th century ideologically connected this Einzelsprache to the ethnolinguistically and racially defined nation of "white" Afrikaners. Although they are a numerical minority, the Afrikaners dominated the country's politics, economy, and social life till 1994, when democracy and equality for all were granted. Apartheid - defined as the policy of racially and ethnolinguistically "separate development" - did make Afrikaans into a de facto colonial European ("white") language at par with English. In 1925, Afrikaans replaced Dutch and was officially recognized as a co-official language - alongside English - in Britain's colony of South Africa (Willemyns 2013: 222).

Interestingly, the apartheid government of South Africa chose to justify this system of inequality with the central European ideology of ethnolinguistic nationalism. After the Great War, the Entente under US President Woodrow Wilson's leadership, employed this ideology of statehood creation and legitimation for transforming central Europe's multiethnic empires into (ideally) ethnolinguistically homogenous nation-states. This process of implementation was called as "national self-determination," which was viewed positively and is still considered one of the most important principles of international law. Hence, architects of apartheid seized upon this unique PR opportunity to counter any accusations of racism, by stating that they would create ethnolinguistically defined nation-states for South Africa's indigenous ("black") ethnic groups in accordance with this principle. And they did, beginning in the 1960s. However, only 14 percent of the country's territory was set aside for the "black homelands," which critics disparaged as "bantustans," or "black ghetto-like states." Most of the South Africa's population was expected to squeeze into this small corner of the country, and the rest of the land would be used exclusively by white and "colored" South Africans. Indigenous Bantu languages - such as Tswana, Xhosa or Zulu were employed in the administration and education across these unilaterally created ethnolinguistic nation-states resulting in their rapid standardization toward western-style Einzelsprachen. However, the legally enforced condition 
that Tswana-, Xhosa- or Zulu-speakers living and working in Cape Town or Johannesburg must "go back" to their "homeland" (nation-state) to continue the education through the medium of their "native language," rather than preferred English, was seen by the concerned persons as highly discriminatory.

Obviously, schools and universities teaching in the media of indigenous ("black") languages had lower budgets and worse facilities than the "white" counterparts outside the bantustans with English and Afrikaans as languages of instruction. Unsurprisingly, the majority of the Tswanas, Xhosas, or Zulus considered this imposition of compulsory education in their L1 languages ("mother tongues") as yet another form of apartheid discrimination. They wanted to become full and equal citizens of all of South Africa, and to this end preferred education in English for their children. Apartheid officials feigned being astounded by this negative reaction and pointed to the example of central Europe where ethnolinguistic national movements for long decades had clamored for education in their "national" (indigenous, L1) languages and for ethnolinguistically defined independent nation-states. However, they overlooked the fact that it was the concerned ethnic groups ${ }^{13}$ who demanded political solutions of this type in central Europe, while in South Africa these institutional and political solutions were imposed by the dominating whites on the "black nations." The system of "black homelands" with "black (native)" languages, was extended to South Africa's mandate of South West Africa (Namibia). Actually, four such "black" nation-states were granted full independence in South Africa, namely Bophutatswana for the Tswanas, Ciskei and Transkei for the Xhosas, and Venda for the Vendas. The independence of Namibia (1990) and the final dismantling of apartheid (1994) brought an end to this system of autonomous and independent "black" ethnolinguistic nation-states (Kaura 1995). Yet, its vestiges remained or resulted in the unusual recognition of as many as 11 languages as official in post-apartheid South Africa, That is, Sepedi, Sesotho, Setswana, siSwati, Tshivenda, Xitsonga, Afrikaans, English, isiNdebele, isiXhosa, and isiZulu (Constitution 1996: Art. 6.1). Nine are indigenous, but in reality English is the dominant Einzelsprache of post-apartheid South Africa's public life and education, even to the extent of marginalizing the semi-indigenous/semi-colonial Einzelsprache of Afrikaans. The same is true of Namibia, where the Constitution designates English additionally as the country's sole official language (Namibian 1998: Art. 3.1).

\footnotetext{
13 Obviously, the term 'concerned ethnic groups' is a shorthand for 'concerned national activists' who claimed to speak on behalf of their prospective nations (ethnic groups). (I thank Jernej Kosi for this important qualification.)
} 
The central European model of ethnolinguistic nation-state was also demonstrated in interwar Ethiopia. The country's modernizing elite borrowed this model from the German Empire by the way of Japan. The indigenous Semitic Einzelsprache of Amharic, written in the indigenous Ethiopic (Ge'ez) script, functioned as Ethiopia's sole national and official language until the 1974 Revolution that overthrew the imperial system. Due to the liberation of the country from Italian occupation with the help of British forces, after World War II, English had become the leading language of education and public life in Ethiopia. In addition, after the revolution, at least 14 more indigenous languages were made into western-style Einzelsprachen. However, their use was typically limited to early elementary education. English and Amharic remained socialist (communist, Soviet) Ethiopia's leading official languages, even though the former Einzelsprache was never designated as such by any piece of legislation. Yet, university-level education in Ethiopia has been invariably available only in English till now. After the fall of communism in Ethiopia (1991), ethnoterritorial federalism was introduced in this highly multiethnic country. By now at least 40 of Ethiopia's over 80 ethnic groups have been granted with autonomous territories, where their indigenous Einzelsprachen are employed as media of education, and sometimes as languages of local administration. Similarly to today's India - where numerous indigenous Einzelsprachen are in use in education and administration in the country's states, but only English and Hindi are used at the federal level - Amharic and English remain Ethiopia's sole languages of federal administration. This model of ethnoterrtitorial federation, as practiced in postcommunist Ethiopia, dates back to the Soviet Union, communist Yugoslavia, and ultimately originated in central Europe's semi-imperial Austria-Hungary (Asnake Kefale, Kamusella and Van der Beken 2021)

In the Horn of Africa, a similar system for accommodating indigenous Einzelsprachen is practiced in Eritrea, which was a part of Ethiopia until 1993. However, the country is not a federation and no language is formally designated as national or official. Instead, the Constitution guarantees equality of all Eritrean languages (Eritrea's Constitution 1997: Art. 4.3). But de facto the non-indigenous idioms of English and Arabic function as the country's official languages and media of education, while the main indigenous Einzelsprache of Tigrinya is used for official purposes only occasionally. Actually, it was ethnolinguistically homogenous postcolonial Somalia which, in 1979, took and enforced the unusual - outside Eurasia decision to employ the indigenous Einzelsprache of Somali as the country's sole official language and medium of education. The Constitution guaranteed the same official status for Arabic, but in actual practice the employment of 
Arabic was limited to religious education in madrasas (Constitution 1979: Art. 3.2). However, in 1991 the nation-state broke up, and nowadays, due to prolonged civil warfare and wide international involvement, English has begun to function as the leading lingua franca in the post-Somalia de facto states (cf Constitution 2005: Art. 6.2).

Confusingly, some propose that Swahili is a good example of an indigenous African language, which is in both the de jure and de facto use in Tanzania to the exclusion of the post/colonial European Einzelsprache of English. Indeed, the employment of Swahili as the leading east African lingua franca is wide, extending from Kenya in the north to Zambia in the south, from the eastern parts of the Democratic Republic of Congo in the west to the Comoros in the Indian Ocean in the east. During the colonial times Swahili was thoroughly "Europeanized" as a western-style Einzelsprache, including the replacement of its originally Arabic script with the Latin alphabet (Fabian 1986: 13, 25 26, 136-162). In Tanzania Swahili is an official language, along with English (Constitution 1977: Art. 67), but only the latter functions as the sole medium of instruction at the country's universities.

In postcolonial Africa nationalism has been invariably assessed positively, but it is understood exclusively as an ethnically-blind ideology of building and reinforcing statehood within the boundaries inherited from the colonial times. Moreover, ethnolinguistic nationalism, typical for Eurasia, is disparaged in Africa as "backward tribalism." In this highly politicized view, the term "tribe" is a normatively potent pejorative for "ethnic group." The situation appears to be a typical example of double standards exposed in the use and application of international law and norms. The principle of national self-determination defined and executed in ethnolinguistic terms has been valued and followed in post-World War I central Europe, or in the wake of the postcommunist breakups of Czechoslovakia, the Soviet Union, and Yugoslavia. Yet, it is heralded as a hallmark of some vague "backwardness" in Africa (cf Okogu 2016; Sharma 1973). Does anyone accuse Czech or Estonian nationalists of "tribalism"? On the contrary, they are portrayed as "patriots of their nation, language, and culture." ${ }^{\prime 14}$

Outside Eurasia, it is assumed that sticking with the former colonial frontiers and a post/colonial European Einzelsprachen would ensure peace, stability, and prosperity. But does it? The telling example is that of Cameroon in central

14 Yet, in the context of central Europe's nation-states, similar pejoratives are used for criticizing "dialect-speakers" who are reluctant to master the official or national language of the state in which they happen to reside. Such a critique often leads to repression against activists, who want such "dialects" to be recognized as languages. (I thank Jernej Kosi for drawing my attention to this aspect.) 
Africa. After the Great War, this German colony was split between France and Britain. In 1960-1961, both colonies gained independence and formed a single nation-state of Cameroon. The subsequent preference for French and Frenchspeakers over English and English-speakers in Cameroon's administration, education, and business, breached the constitutional guarantee of equal bilingualism and marginalized the latter group. The conflict turned violent in 2018-2019, resulting in the death of half a thousand and displacement of half a million. Obviously, till elementary education which was ensured to all in the late 20th century, no Cameroonians spoke French or English as their first languages. Even today the vast majority of 23 million Cameroonians speak the country's 200 or so indigenous Einzelsprachen as their "mother tongues." But when it comes to politics, education, and state-wide (national) identity, for better or worse, Cameroonians now flank either with French or English. Ironically, they struggle and suffer for a European language though this linguistic difference is not of their own making (Cameroon's Deadly 2019; Freeman 2018; Munshi 2019; O'Grady 2019).

A territory in the Americas that however slightly approaches the official use of an indigenous language in administration is Nunavut. ${ }^{15}$ The typical reaction to this proposition is "Where is that?" Nunavut is the most northerly of Canada's provinces and territories. Its sparse and tiny population of 40,000 enjoys the country's two official European Einzelsprachen of English and French, to which, the indigenous language of Inuit (Inuktitut) was cautiously added during the 1990s (Consolidation 2008; Nunavut 1993: Art. 23.1.n). In 2009, next door to Nunavut, in Denmark's autonomous state of Greenland, inhabited by 56,000 people, without much fanfare, Inuit (Kalaallisut) was made the sole official language (Lov 2009: Art. 21). Yet, practically Danish and English dominate the country's public life and education. Furthermore, due to the polity's anomalous status, it is difficult to say whether Greenland should be treated as part of Europe or North America. Geographically speaking, it is a North American country, but from the political perspective,

15 I exclude from the analysis, the system of ghetto-like "reserves, reservations, or indigenous territories," where the remnants of nearly exterminated and ethnically cleansed indigenous ethnic groups ("first nations") were forced, be it in North America or Brazil (cf List of Indian Reservations 2020; List of Indian Reserves 2020; List of Indigenous 2020). Not always, but in most cases these "native ghettoes" are employed for keeping these remnants of the surviving American ethnic groups out of sight, or for the sake of the brutally executed forced assimilation. Unsurprisingly, the use of indigenous languages is stigmatized and discouraged in these ghettoes in preference of the post/colonial European Einzelsprachen (cf Churchill 2005; Gierak-Onoszko 2019; Jarkowiec 2018). A similar system of "Aboriginal reserves" existed in Australia until the turn of the 1970s. Later, indigenous ("Aboriginal") ethnic groups were given the right to reclaim their ancestral lands stolen by European colonizers (Land Won 2020). But this success was not repeated in the case of the indigenous languages, whose decline appears to be unstoppable now. At present only 42,000 persons (or 1.5 percent of Australia's population) are fluent in 46 indigenous languages (Australian 2020). 
Greenland as part of Denmark is more tightly attached to Europe. Similar to Oceania's small island nation-states discussed above, both Greenland and Nunavut may be seen as a "transitory borderland" between Eurasia and the Rest of the world in terms of the preferred pattern of official language use.

\section{Out of Synch in Eurasia: Rejecting Indigenous Languages}

In Eurasia, the standardization (construction) and choice of an indigenous Einzelsprachen for the role of national (official, state) language in a nationstate always excludes other indigenous Einzelsprachen (typically disparaged as "dialects") spoken (and often written) across the nation-state's territory. Yet, as emphasized above, never a non-Eurasian Einzelsprache has been selected as an official language for a Eurasian polity. Perhaps, with the lonely exception of the aforementioned special case of autonomous Greenland, should this country be treated as part of Eurasia on the strength of its political association with Denmark.

In rare cases, a Eurasian Einzelsprache is chosen as official for a polity due to the vagaries of history or for political reasons, though it is not indigenous to the country's territory or population. For instance, in Europe, this is the case of Belarus and Ireland. In the latter nation-state, the Celtic language of Irish is the national and official language (Constitution 1937: Art. 8.1), but in reality it is English that plays this role, though this Germanic Einzelsprache is constitutionally designated only as " $a$ second official language" (Constitution 1937: Art. 8.2). Both Belarusian and Russian are closely related Slavic Einzelsprachen. Most Belarusians see the former as their national and indigenous language, but the Constitution recognizes both as the country's equal and official languages (Constitution 1994: Art. 19). In reality the state administration prefers Russian; more than 90 percent of the population speaks Russian in everyday life, and no university uses Belarusian as a leading medium of education (Barushka 2015).

Glancing at the map of Eurasia, one can easily observe that the correlation between indigenous languages, their speech communities, and states is the highest in Europe, and especially in central and eastern Europe. In this area of the continent, nation-states with the population of about 1 million people (Cyprus or Latvia), 2 million (North Macedonia or Slovenia), or 5 million (Finland or Slovakia) are not unusual. Typically, the smaller a population is the more homogenous it tends to be in a polity's official (main) indigenous language. This correspondence was rather poor in the postwar Soviet Union (SU), yet its constituent republics operated also in their indigenous ("titular") languages, apart from the communist polity's sole "federal" Einzelsprache of 
Russian. The breakup of the SU in 1991 made these 15 constituent republics into independent ethnolinguistic nation-states in their own right. In most cases, Russian was sidelined or replaced by the republican titular Einzelsprache in the role of state and national language.

However, the Russian Federation remains highly multiethnic, with nonRussian ethnic groups accounting for at least a fifth of the country's inhabitants. Nowadays, there are 22 autonomous republics based on these ethnic groups with more than 20 different (or over 30, if all Dagestan's languages are taken into consideration) Einzelsprachen in the function of official languages and that of media of education. But, all the country's secondary schools and universities employ exclusively Russian as their language of instruction. The parliaments of all the autonomous republics provide information on their websites in Russian and only in ten republican languages (Bashkir, Buriat, Crimean Tatar, Chuvash, Circassian, Komi, Tatar, Udmurt, Ukrainian, and Yakut). More than 50 book titles per annum are published just in four non-Russian languages (that is, Bashkir, Chuvash, Tatar, and Yakut) (Gosudarstvennye 2020; Iazykovaia 2020). Hence, Russia appears to be on the course of doing away with the official and public use of any other indigenous languages than Russian. In equally multiethnic China at least 112 million people belong to ethnically non-Chinese (non-Han) ethnic groups. It is a staggering number equal to that of all ethnic Russians living in today's Russia. However, these speakers of non-Chinese languages account for less than a tenth of China's inhabitants (Demographics 2020). At present, it appears that Beijing is intent on assimilating all these non-Chinese-speakers as quickly as possible, officially for the sake of ending poverty, but in reality the intention is to create an ethnolinguistically homogenous nation-state of China (Anand 2019; Davidson 2020).

As mentioned above, the indifference to and negligence of other indigenous languages than the designated national Einzelsprache in southeast Asia's nation-states is dictated by the logic of ethnolinguistic nationalism. A similar outcome can be observed in highly multiethnic Iran and Pakistan. But in these countries the decision on making a single language official (national) and the exclusion of others is underwritten by confessional nationalism, followed in the interest of building an Islamic republic. In turn, present-day Afghanistan, like India, allows for the use of multiple indigenous languages (Constitution 1382 [2004CE]: Art. 16). But due to prolonged and extensive foreign and international involvement in this country since the turn of the 1970s, nowadays English is Afghanistan's main lingua franca, making the country's language politics even more similar to India's. 


\section{Politics of Script: Latin Alphabet $=$ Cultural Imperialism}

The cleavage between Eurasia and the Rest of the world in language politics is even clearer when this split is observed from the perspective of script. The technology of writing was invented independently, perhaps, only four times in history, namely, in Mesopotamia, China, Mesoamerica, and the Andes (Clayton 2019). Hence, the invention was twice in Eurasia and twice outside it. But European conquistadors and colonizers extinguished these two indigenous traditions of writing in the Americas. As a result, only the Eurasian technologies of writing survive till now. The Chinese tradition is limited now to east Asia, namely, China, Japan, Korea, and Taiwan. Elsewhere in Eurasia and across the Rest of the world, different kinds of Mesopotamia-style writing are now in use.

A multitude of unique scripts are employed across south and southeast Asia. Present-day India is the world's most polyscriptal ${ }^{16}$ polity with 22 indigenous languages that are currently official in the country's 28 states. Half of these Einzelsprachen are written in their specific scripts; whereas Bodo, Dogri, Konkani, Maithili, Marathi, Nepali, and Sanskrit share the Devanagari writing system of India's (constitutionally designated) national language of Hindi. Similarly, the Arabic script is shared by the three state-level official languages, namely, Kashmiri, Sindhi, and Urdu (92nd Constitutional 2004). ${ }^{17}$ Significantly, Urdu, one of these Arabic script-based Einzelsprachen is also Pakistan's sole national and official language.

In southeast Asia, typically, a script is in exclusive use for writing and printing a given ethnolinguistically defined nation-state's single national language. For instance, in Thailand the national Einzelsprache of Thai is written in the unique and eponymous Thai script, which is not employed for any other languages. Hence, the Thai writing system is a proper national script. Outwith southeast Asia, unique national scripts are employed for writing the national languages of Armenian in Armenia, Georgian in Georgia, and Hebrew in Israel. The Greek alphabet is used exclusively for writing the Greek language, but this Einzelsprache is the official and national language in two nationstates, namely, Cyprus and Greece.

16 How to form an adjective from the noun "script"? When a decade ago, I began writing about the politics of script (writing), some proposed the adjectival form should read "scriptural." Unfortunately, an immediate association with some "holy scriptures" sprang up. But should the word be pruned of the second letter [r], yielding "scriptual," this form was mostly liberated from this unwanted association. Yet, in this text I use now "scriptal," following the example of Bunčić, Lippert and Rabus (2016), who authored an authoritative monograph on the subject of biscriptality.

17 Apart from the approved official scripts for India's official languages, these languages' speakers tend to use a variety of unofficial scripts, due to their religion or influence from other languages written in different scripts. 
Elsewhere in the world, the Arabic, Latin, and Cyrillic writing systems dominate. Apart from the Arabic language, the Arabic script is employed for a variety of other languages in the ideologically Islamic nation-states from Pakistan and Iran in southwestern Asia to the Arabic Peninsula and north Africa in the west. Cyrillic is employed with the national languages of the ideologically Orthodox Slavophone nation-states in the Balkans, that is, in Bulgaria, Montenegro, North Macedonia, and Serbia. Otherwise, the employment of this alphabet used to be quite tightly correlated with the territory of the Soviet Union and its Asian satellite of Mongolia. After the breakup of this communist polity, the post-Soviet states of Azerbaijan, Moldova, Turkmenistan, and Uzbekistan decided to write their eponymous national languages in Latin letters. At present, Kazakhstan is in the process of superseding Cyrillic with the Latin alphabet for writing the national and official language of Kazakh.

In Eurasia, the Latin alphabet dominates across most of Europe, in Turkey, in the post-Soviet Turkic nation-states (Azerbaijan, Kazakhstan, Turkmenistan and Uzbekistan) and in the eastern half of southeast Asia (Brunei, East Timor, Indonesia, Malaysia, Papua New Guinea, the Philippines, and Vietnam). The Latin script is indigenous to Europe. It was the post-Ottoman Turkey's sovereign decision to switch from Arabic to Latin letters for writing Turkish in 1928. The interwar period was most probably the high age of western (European) imperialism. Unsurprisingly, in the eyes of Turkey's secular republican elite, the Latin alphabet appeared to be the script of modernity and progress (read: power). After the collapse of the SU, the post-Soviet Turkic nation-states decided to replace Cyrillic with the Latin alphabet in emulation of republican Turkey, and as a postcolonial (anti-colonial) reaction to the former Russian/Soviet political and cultural domination. Yet, the presence of the Latin alphabet in southeast Asia is a clear legacy of Europe's maritime colonial empires, like across the Rest of the world.

Outside Eurasia, the non-indigenous Latin alphabet dominates almost absolutely, with the exception of the Ethiopic (Ge'ez) script which is used for writing Ethiopia's federal Einzelsprache of Amharic along with some other indigenous languages in this country. Western (European) colonial domination either introduced the Latin alphabet or replaced indigenous writing systems with it. Since the colonizing pressure was so strong until the mid-20th century, the Latin alphabet was often equated and confused with "modernization and progress" in non-European countries. For example, in east Asia serious projects were considered for replacing the Chinese script with Latin letters for writing and publishing in Chinese, Japanese, Korean, 
and Vietnamese (cf DeFrancis 1984: 235). The legacy of this trend is the Vietnamese Latin alphabet (Chữ Quốc ngữ) (Gunn 2003: 242), alongside the ubiquitous Romanizations of Chinese, Japanese, and Korean names and inscriptions on road signs and in public notices across China, Japan, and both Koreas. These Romanization systems - referred to as Pinyin, Romaji, and Romaja, respectively - function as unofficial "Latin alphabets" of Chinese, Japanese, and Korean.

The exclusive use of the non-indigenous Latin alphabet for writing and publishing in the Rest of the world clearly marks the cleavage between it and Eurasia. Not only are non-indigenous European Einzelsprachen cast in the role of official and national languages across the Rest of the world, but also all of them are written in non-indigenous Latin letters. From the perspective of the politics of language and script, the Rest of the world can be considered an extension of Europe, a monoscriptal neo-Europe. The same is also true for much of central and southeast Asia where the Latin script is employed. What is more, to a large degree Russian colonialism (imperialism) has been also European (western) in its character, at least, since the turn of the 18th century, when Muscovy (Russia) embarked on modernizing (that is, westernizing, Europeanizing) reforms. Hence, the use of Cyrillic across northern Asia and parts of central Asia (alongside Russian as the preferred lingua franca) is indicative of European (western) colonial domination, though Russianinflected. That is how extensive and pervasive European (western) cultural and linguistic imperialism is nowadays. This imperialism's most obvious and readily visible "logos" are the Latin and Cyrillic alphabets.

However, people who write and read in scripts other than the Latin alphabet, usually have a working knowledge of Latin letters. They use the Latin writing system for Romanization, to write down names of western personalities (in order to avoid confusion involved, when these are transliterated into another script), at times on car license plates, and obviously when they acquire a western (European) Einzelsprache. Contrarily, the users of Latin letters almost never reciprocate this gesture by acquiring even a rudimentary command of a non-Latin script. Nowadays the Latin alphabet is more "global" (that is, dominant) in its character than the "world language" of English. But somehow, this form of imperialism, scriptal imperialism, evades any explicit scrutiny.

\section{Conclusion: Cyberspace, or the Latest Frontier}

During the 1990s, after the fall of communism and the end of the Cold War, the worldwide "inter-network" was launched for the advantage of population 
at large. The internet arrived with the democratic promise that it would be readily available for "free" and provide "unbiased" information to everyone. But initially, the web was available in English and Latin letters only. Even today, 60 percent of the content available across the internet is in English only. The distant second language is Russian, in which 8.6 percent of the web's content is written. The overwhelming bulk of the internet content comes in European Einzelsprachen. The little remaining chunk is available in Asian languages - mainly in Turkish, Persian, Japanese, Chinese, Vietnamese, Arabic, Indonesian, Thai, Hebrew and Hindi - that collectively account for almost 14 percent of the content. Whatever content is provided through the medium of non-Eurasian languages, it is so little in comparison to the overall bulk of the internet that such content does not really show up in any general statistics (Usage 2020).

Wikipedia, now available in over 300 Einzelsprachen, is also a useful yardstick for assessing the disparity in internet-cum-linguistic divide between Eurasia and the Rest of the world. All the Wikipedias in May 2020 contained $53,535,000$ articles, but a mere 232,000 (0.4\%) articles were offered in nonEurasian languages. Readers could enjoy 159,000 articles in the Wikipedias written in African Einzelsprachen (excluding Afrikaans and Arabic), 56,000 articles in American languages, and 17,000 articles in Oceania's indigenous Einzelsprachen. At the same time, the Afrikaans Wikipedia boasted 91,000 articles and the Arabic Wikipedia - 1,046,000 articles, so together seven times more than in all the Wikipedias written in Africa's indigenous Einzelsprachen. At least 33,974,000 (63.5\%) Wikipedia articles could be accessed in European languages, which indicates well the staggering level of western (European) cultural and linguistic imperialism in today's world (List of Wikipedias 2020).

Decolonization of culture and language politics is not on the cards anytime soon. Some equality in this context has been achieved only in Eurasia, and especially in Europe, mainly central Europe with its plethora of ethnolinguistically defined nation-states. In any foreseeable future, sadly, members of indigenous ethnic groups and speakers of indigenous languages in the Rest of the world are bound to suffer the continuing indignity of the imposition of post/colonial European languages on their communities, cultures, and polities.

\section{References}

92nd Constitutional Amendment Act: Constitutional Provisions Relating to Eighth Schedule. 2004. https://web.archive.org/web/20160305010536/http://mha.nic.in/hindi/sites/upload_files/mhahindi/files/pdf/Eighth_Schedule.pdf. Accessed: May 31, 2020. 


\section{Global Language Politics: Eurasia versus the Rest}

Achebe, Chinua. 1958. Things Fall Apart (Ser.: African Writers Series, Vol. 1). London: Heinemann.

Anand, Dibyesh. 2019. Colonization with Chinese Characteristics: Politics of (In)Security in Xinjiang and Tibet (pp 129-147). Central Asian Survey. Vol. 38, No. 1.

Article 343 in The Constitution Of India 1949. 1949. https://indiankanoon.org/doc/379861/. Accessed: Oct 19, 2020.

Asnake Kefale; Kamusella, Tomasz and Van der Beken, Christophe. 2021 [Forthcoming]. The Ethiopian Nation-State and Central Europe: Between the German Empire and AustriaHungary. London: Routledge.

Australian Aboriginal Languages: Living Aboriginal Languages. 2020. Wikipedia. https:// en.wikipedia.org/wiki/Australian_Aboriginal_languages\#Living_Aboriginal_languages. Accessed: May 30, 2020.

Benedikter, Thomas. 2009. Language Policy and Linguistic Minorities in India: An Appraisal of the Linguistic Rights of Minorities in India (Ser.: Lit Studies on India, Vol. 3). Münster: Lit Verlag.

Barushka, Katerina. 2015. After Decades of Russian Dominance, Belarus Begins to Reclaim Its Language. The Guardian. 28 Jan. https:/www.theguardian.com/world/2015/jan/28/sp-russian-belarus-reclaims-language-belarusian. Accessed: May 30, 2020.

Breton, Roland L.-J. 1999. Atlas of the Languages and Ethnic Communities of South Asia. New Delhi: Sage Publications.

Bunčić, Daniel; Lippert, Sandra L. and Rabus, Achim. eds. 2016. Biscriptality: A Sociolinguistic Typology (Ser: Akademiekonferenzen, Vol. 24). Heidelberg: Universitätsverlag Winter.

Burrows, Genna. 2016 [PhD dissertation]. The Politics of Arabic Script. Canberra: Australian National University. https://core.ac.uk/download/pdf/156712577.pdf. Accessed: Oct 19, 2020.

Cameroon's Deadly Battle Over Language. 2019. Al Jazeera. 12 Apr. https://www.aljazeera. com/podcasts/thetake/2019/04/cameroon-deadly-battle-language-190412143608732. html. Accessed: Sept 12, 2019.

Cavanagh, Edward and Veracini, Lorenzo, eds. 2017. The Routledge Handbook of the History of Settler Colonialism. London: Routledge.

Churchill, Ward. 1993. Struggle for the Land: Indigenous Resistance to Genocide, Ecocide, and Expropriation in Contemporary North America. Monroe ME: Common Courage Press.

Churchill, Ward. 2005. Kill the Indian, Save the Man: The Genocidal Impact of American Indian Residential Schools. San Francisco CA: City Lights.

Clayton, Ewan. 2019. Where Did Writing Begin? London: British Museum. https://www. bl.uk/history-of-writing/articles/where-did-writing-begin. Accessed: Oct 19, 2020.

Considine, John. 2017. Academy Dictionaries, 1600-1800. Cambridge: Cambridge University Press.

Consolidation of Inuit Language Protection Act. 2008. https://web.archive.org/ web/20170516050222/http://www.gov.nu.ca/sites/default/files/gnjustice2/justicedocuments/Consolidated\%20Law/Current/635199485609218750-1283713084-consSNu2008c17.pdf. Accessed: May 29, 2020. 


\section{Journal of Nationalism, Memory \& Language Politics 14(2)}

Constitutional Provisions Relating to Eighth Schedule. 2020. https://www.mha.gov.in/sites/ default/files/EighthSchedule_19052017.pdf. Accessed: Oct 19, 2020.

Constitution of Afghanistan. 1382 (2004CE). https://web.archive.org/web/20131028065437/ http://www.afghan-web.com/politics/current_constitution.html. Accessed: May 30, 2020.

Constitution of Ireland. 1937. http://www.irishstatutebook.ie/eli/cons/en\#part1. Accessed: May 30, 2020.

Constitution of Kiribati. 1995. https://www.wipo.int/edocs/lexdocs/laws/en/ki/ki001en.pdf. Accessed: May 24, 2020.

Constitution of the Commonwealth of the Northern Mariana Islands. 1994. https:// en.wikisource.org/wiki/Constitution_of_the_Commonwealth_of_the_Northern_Mariana_Islands. Accessed: May 24, 2020.

Constitution of the Independent State of Papua New Guinea. 1975. www.paclii.org/pg/legis/ consol_act/cotisopng534/. Accessed: May 24, 2020.

Constitution of the Independent State of Samoa. 1997. https://www.legal-tools.org/doc/ee8a3d/pdf/. Accessed: May 25, 2020.

Constitution of the Islamic Republic of Pakistan. 2012. Islamabad: National Assembly of Pakistan. http://www.na.gov.pk/uploads/documents/1333523681_951.pdf. Accessed: May 24, 2020.

Constitution of the Republic of Belarus. 1994. https://www.wipo.int/edocs/lexdocs/laws/en/ by/by016en.pdf. Accessed: May 30, 2020.

Constitution of the Republic of Fiji. 2013. www.paclii.org/ff/Fiji-Constitution-English-2013. pdf. Accessed: May 25, 2020.

Constitution of the Republic of Palau. 1979. https://wipolex.wipo.int/en/text/200951. Accessed: May 24, 2020.

Constitution of the Republic of Somaliland. 2005. www.somalilandlaw.com/body_somaliland_constitution.htm. Accessed: May 28, 2020.

Constitution of the Republic of South Africa. 1996. https:/www.gov.za/sites/default/files/ images/a108-96.pdf. Accessed: May 28, 2020.

Constitution of the Somali Democratic Republic. 1979. www.nuhanovicfoundation.org/user/ file/1979_somalia_constitution.pdf. Accessed: May 28, 2020.

Crosby, Alfred. 1986. Ecological Imperialism: The Biological Expansion of Europe, 900-1900. Cambridge: Cambridge University Press.

Davidson, Helen. 2020. Inner Mongolia Protests at China's Plans to Bring in Mandarin-Only Lessons. The Guardian. 1 Sept. https:/www.theguardian.com/world/2020/sep/01/innermongolia-protests-china-mandarin-schools-language. Accessed: Oct 19, 2020.

DeFrancis, John. 1984. The Chinese Language: Fact and Fantasy. Honolulu HI: University of Hawaii Press.

Demographics of China: Ethnic Groups. 2020. Wikipedia. https:/en.wikipedia.org/wiki/Demographics_of_China\#Ethnic_groups. Accessed: May 30, 2020.

Dunbar, Robin I. M. 1992. Neocortex Size as a Constraint on Group Size in Primates (pp. 469-493). Journal of Human Evolution. Vol. 22, No. 6. 


\section{Global Language Politics: Eurasia versus the Rest}

Dunbar, Robin I. M. 2010. How Many Friends Does One Person Need? Dunbar's Number and Other Evolutionary Quirks. London: Faber and Faber.

Eritrea's Constitution of 1997. 1997. https://www.constituteproject.org/constitution/Eritrea_1997.pdf?lang=en. Accessed: May 28, 2020.

Fabian, Johannes. 1986. Language and Colonial Power: the Appropriation of Swahili in the Former Belgian Congo 1880-1938. Berkeley CA: University of California Press.

Figueira, Carla. 2013. Languages at War: External Language Spread Policies in Lusophone Africa, Mozambique and Guinea-Bissau at the Turn of the 21st Century (Ser: Duisburger Arbeiten zur Sprach- und Kulturwissenschaft, Vol. 97). Frankfurt am main: Peter Lang.

Foreman, Grant. 1932. Indian Removal: The Emigration of the Five Civilized Tribes of Indians. Norman OK: University of Oklahoma Press.

Freeman, Colin. 2018. Bitter Linguistic Divide is Pushing Cameroon Over the Edge. $N$ World. 6 Oct. https://www.thenational.ae/world/africa/bitter-linguistic-divide-is-pushingcameroon-over-the-edge-1.777719. Accessed: Sept 12, 2019.

Fukuyama, Francis. 1992. The End of History and the Last Man. New York: Perennial.

Gierak-Onoszko, Joanna. 2019. 27 śmierci Toby'ego Obeda. Warsaw: Dowody na Istnienie.

Gil, Jeffrey. 2019. Will Mandarin Be the Next Global Language? Asia Times. 25 Mar. https:// asiatimes.com/2019/03/will-mandarin-be-the-next-global-language/. Accessed: May 16, 2020.

Gosudarstvennye i ofitsial'nye iazyki v sub”ektakh Rossiiskoi Federatsii. 2020. Vikipediia. https://ru.wikipedia.org/wiki/Государственные_и_ојициальные_языки_в_субъектах_ Российской_Fедерации. Accessed: May 30, 2020.

Government of Pakistan: Population by Mother Tongue. с 2014. https://web.archive.org/ web/20060217220529/http://www.statpak.gov.pk/depts/pco/statistics/other_tables/pop_ by_mother_tongue.pdf. Accessed: May 24, 2020.

Gunn, Geoffrey C. 2003. First Globalization: The Eurasian Exchange, 1500-1800. Lanham MD: Rowman \& Littlefield.

Gunnemark, Erik. 1992. Countries, Peoples and Their Languages: The Geolinguistic Handbook (Vol. 1). Gothenburg: Geolingua.

Harring, Sidney L. 1998. White Man's Law: Native People in Nineteenth-Century Canadian Jurisprudence. Toronto: University of Toronto Press.

Hroch, Miroslav. 1985. Social Preconditions of National Revival in Europe: A Comparative Analysis of the Social Composition of Patriotic Groups among the Smaller European Nations [translated from the German by Ben Fowkes]. Cambridge: Cambridge University Press.

Iazykovaia politika v Rossii. 2020. Vikipediia. https://ru.wikipedia.org/wiki/Языковая_ политика_в_России. Accessed: May 30, 2020.

Jarkowiec, Maciej. 2018. Powróce jako Piorun. Krótka historia Dzikiego Zachodu. Warsaw: Wydawnictwo Agora.

Judson, Pieter M. 2016. The Habsburg Empire: A New History. Cambridge MA: Harvard Univeristy Press. 


\section{Journal of Nationalism, Memory \& Language Politics 14(2)}

Kamusella, Tomasz. 2016. The History of the Normative Opposition of 'Language versus Dialect:' From Its Graeco-Latin Origin to Central Europe's Ethnolinguistic Nation-States (pp 189-198). Colloquia Humanistica. Vol 5.

Kamusella, Tomasz. 2017. The Arabic Language: A Latin of Modernity? (pp 117-145). Journal of Nationalism, Memory and Language Politics. Vol. 11, No. 2.

Kaura, Abnasha. 1995. South Africa and Bantustans. Delhi: Kalinga Publications.

Kaye, Alan S. 1997. 14 Arabic Dialects and Maltese (pp 263-311). In: Alan S. Kaye and Judith Rosenhouse, eds. The Semitic Languages. London: Routledge.

Kemiläinen, Aira. 1964. Nationalism: Problems Concerning the Word, the Concept and Classification (Ser: Studia historica Jyväskyläensia, Vol. 3). Jyväskylä: Jyväskylän Kasvatusopillinen Korkeakoulu, Jyväskylän Yliopistoyhdistys and Jyväskylan Yliopisto.

Land Won Back. 2020. https://www.clc.org.au/articles/cat/land-won-back/. Accessed: May 30, 2020.

List of Indian Reservations in the United States. 2020. Wikipedia. https://en.wikipedia.org/ wiki/List_of_Indian_reservations_in_the_United_States. Accessed: May 30, 2020.

List of Indian Reserves in Canada. 2020. Wikipedia. https://en.wikipedia.org/wiki/List_of_ Indian_reserves_in_Canada. Accessed: May 30, 2020.

List of Indigenous Territories (Brazil). 2020. Wikipedia. https://en.wikipedia.org/wiki/List_ of_indigenous_territories_(Brazil). Accessed: May 30, 2020.

List of Wikipedias by language group. 2020. Wikimedia: Meta-Wiki. https://meta.wikimedia. org/wiki/List_of_Wikipedias_by_language_group. Accessed: May 31, 2020.

Lov om Grønlands Selvstyre. 2009. Lovtidende A. No 473. 13 Jun. https://www.stm.dk/multimedia/selvstyreloven.pdf. Accessed: May 29, 2020.

Māori Language Act. 1987. https://web.archive.org/web/20120207104608/http://www. tetaurawhiri.govt.nz/act87/3.shtml. Accessed: May 30, 2020.

Marshall Islands' Constitution of 1979 with Amendments through 1995. 1995. https://www. constituteproject.org/constitution/Marshall_Islands_1995.pdf?lang=en. Accessed: May 24, 2020 .

Munshi, Neil. 2019. Cameroon Separatist Crisis Prompts Call for 'National Dialogue.' The Financial Times. 10 Sept. https://www.ft.com/content/70cb8fcc-d411-11e9-a0bdab8ec6435630. Accessed: Sept 12, 2019.

Namibian Constitution. 1998. https://www.lac.org.na/laws/annoSTAT/Namibian\%20Constitution.pdf. Accessed: May 29, 2020.

Ngā puna kōrero: Where Māori Speak Te Reo - Infographic. 2015. http://archive.stats.govt. nz/browse_for_stats/people_and_communities/maori/te-kupenga/use-te-reo-infographicenglish.aspx. Accessed: May 30, 2020.

Nunavut Act. 1993. https://laws-lois.justice.gc.ca/eng/acts/N-28.6/index.html. Accessed: May 29, 2020.

O'Grady, Siobhán. 2019. War of Words: Cameroon Being Torn Apart by Deadly Language Division. The Independent. 27 Feb. https:/www.independent.co.uk/news/world/cameroonlanguage-french-english-military-africa-ambazonia-a8770396.html. Accessed: Sept 12, 2019. 
Okogu, J. O. 2016. Tribalism as a Foiled Factor of Africa Nation-Building (pp 92-94). Journal of Education and Practice. Vol. 7. No. 7. https://files.eric.ed.gov/fulltext/EJ1095249.pdf. Accessed: May 30, 2020.

Penduduk Indonesia Hasil Sensus Penduduk 2010/Result of Indonesia Population Census 2010. 2012. Jakarta: Badan Pusat Statistik. https://web.archive.org/web/20150402221528/http:// www.bps.go.id/index.php/publikasi/14. Accessed: May 24, 2020.

Phillipson, Robert. 1992. Linguistic Imperialism. Oxford: Oxford University Press.

Rahman, Tariq. 2011. From Hindi to Urdu: A Social and Political History. New Delhi: Orient BlackSwan.

Saussure, Ferdinand de. 1983. Course in General Linguistics (edited by Charles Bally and Albert Sechehaye with the collaboration of Albert Riedlinger; translated from the French and annotated by Roy Harris). London: Duckworth.

Sharma, Bishan S. 1973. Politics of Tribalism in Africa To-day. Delhi: Department of African Studies. Delhi University.

Slugget, Peter and Currie, Andrew. 2014. Atlas of Islamic History. London: Routledge.

Stoll, David. 1982. Fishers of Men or Founders of Empire? The Wycliffe Bible Translators in Latin America. London: Zed Press.

Thomas, Martin; Moore, Bob and Butler, L. J. 2010. Crises of Empire: Decolonization and Europe's Imperial States, 1918-1975. London: Bloomsbury Academic.

Thurner, Mark. 2019. The First Wave of Decolonization (Ser.: Routledge Studies in Global Latin America). London: Routledge.

Usage Statistics of Content Languages for Websites. 2020. W3Techs. 25 Mar. https://w3techs. com/technologies/overview/content_language. Accessed: May 31, 2020.

Van Rooy, Raf. 2019. $\Delta \dot{\alpha} \lambda \lambda_{\varepsilon \kappa \tau} \circ$, Dialectus, Dialect: A Word's Curious Journey from Ancient Greek to (Neo-)Latin and Beyond (pp 733-770). Latomus: Revue d'études latines. Vol. 78, No. 3.

Vanuatu's Constitution of 1980 with Amendments through 2013. 2013. https://www.constituteproject.org/constitution/Vanuatu_2013.pdf?lang=en. Accessed: May 25, 2020.

Weber, Eugen. 1976. Peasants into Frenchmen: Modernization of Rural France, 1870-1914: The Modernization of Rural France, 1870-1914. Stanford CA: Stanford University Press.

Wexler, Paul. 1990. The Schizoid Nature of Modern Hebrew: A Slavic Language in Search of a Semitic Past (Ser: Mediterranean Language and Culture, Vol. 4). Wiesbaden: Harrassowitz.

Willemyns, Roland. 2013. Dutch: Biography of a Language. Oxford: Oxford University Press.

Wolf, Eric R. 1982. Europe and the People Without History. Berkeley CA: University of California Press. 